\title{
Interactive teaching and learning with smart phone app in Optoelectronic Instruments course
}

Yao Hu, Qun Hao, Ya Zhou, Yifan Huang

Yao Hu, Qun Hao, Ya Zhou, Yifan Huang, "Interactive teaching and learning with smart phone app in Optoelectronic Instruments course," Proc. SPIE 10452, 14th Conference on Education and Training in Optics and Photonics: ETOP 2017, 104521U (16 August 2017); doi: 10.1117/12.2269504

SPIE Event: 14th Conference on Education and Training in Optics and Photonics, ETOP 2017, 2017, Hangzhou, China 


\title{
Interactive teaching and learning with smart phone App in Optoelectronic Instruments course
}

\author{
Yao Hu*, Qun Hao, Ya Zhou, Yifan Huang \\ Beijing Key Lab. for Precision Optoelectronic Measurement Instrument and Technology, \\ School of Optoelectronics, Beijing Institute of Technology, Beijing 100081, China
}

\begin{abstract}
Optoelectronic Instruments is a comprehensive professional course for senior students majored in optical engineering and similar specialties. Due to the low lecturer/ student ratio, typically less than 1:100, most of the students gave up the chance of one-to-one communication with the lecturers even when they were confused about the principle or applications of the instruments. A smart phone App Rain Classroom associated with messaging App Wechat is introduced. It enables the lecturers to receive instant feedback from students through bullet screen, push preview and review materials and post in-class quiz. Investigation also shows that $76 \%$ of the students enjoyed the new interactive tool, acknowledging its help in understanding the topic better, improving in-class interaction, and after class communications.
\end{abstract}

Keywords: interactive teaching and learning, smartphone App, bullet screen, information pushing, optoelectronic instrument course

\section{INTRODUCTION}

As the development of computer science and information technique, the media for education has increased from penand-paper to computer, projector, and recently personal digital assistant, mobile phone and smartphone. Different teaching methodologies and their impacts on students' thoughts and psychology development have been studied [1-3]. As for the use of smartphone and social software, example scenarios are outlined [4-6]. In this paper, we propose a trial of using smartphone and social software for the teaching and communication in a senior grade engineering course.

\section{INTRODUCTION TO OPTOELECTRONIC INSTRUMENTS COURSE}

\subsection{Course objective}

OIC is a 48 hours course for the senior students in School of Optoelectronics, Beijing Institute of Technology. The objective of OIC is to familiarize students with the operating principles and basic design principles of commonly used optoelectronic instruments. Students will be able to describe the operating procedure of the instruments, distinguish the structure and function of each part, analyze the accuracy of measurement method and a specific system, and present preliminary results of both overall design and parameter design.

\subsection{Course content}

The main topics of the course start from basic physical principles adopted in optoelectronic instruments, and cover accuracy analysis of measuring instrument and modern instrument design methods such as ergonomics or optimum design. The focused functional parts include light sources, optical elements, detectors and metrical standards. Micro displacement technology for precision instruments and common alignment schemes are also introduced. Instances of conventional instruments like interferometers and microscopes are proposed to train the students to apply principles to specific practical problems. The detailed contents of OIC are listed in Table. 1.

*huy08@bit.edu.cn

14th Conference on Education and Training in Optics and Photonics: ETOP 2017, edited by Xu Liu,

Xi-Cheng Zhang, Proc. of SPIE Vol. 10452, 104521U · (c) 2017 ICO, IEEE, OSA, SPIE

CCC code: $0277-786 X / 17 / \$ 18 \cdot$ doi: $10.1117 / 12.2269504$

Proc. of SPIE Vol. $10452104521 \mathrm{U}-1$ 
Table 1. Detailed contents of OIC

\begin{tabular}{|c|c|c|}
\hline Chapter & Contents & Class hour \\
\hline 1. Introduction & $\begin{array}{l}\text { - History and development of optoelectronic instruments } \\
\text { - Classification and construction of optoelectronic instruments } \\
\text { - Basic methodology for general design }\end{array}$ & 4 \\
\hline $\begin{array}{l}\text { 2. Accuracy analysis and } \\
\text { design }\end{array}$ & $\begin{array}{l}\text { - Definition and source of errors } \\
\text { - Methods for error analysis and calculation } \\
\text { - Composition of errors } \\
\text { - Error budget } \\
\text { - Basic design criteria for improving the accuracy } \\
\text { - Error compensation }\end{array}$ & 6 \\
\hline $\begin{array}{l}\text { 3. Modern design method } \\
\text { for instruments }\end{array}$ & $\begin{array}{l}\text { - Design methodology } \\
\text { - Ergonomic } \\
\text { - Optimization } \\
\text { - Finite element analysis } \\
\text { - Reliability design }\end{array}$ & 2 \\
\hline 4. Measurement standards & $\begin{array}{l}\text { - Introduction to metrology } \\
\text { - Ruler and dial } \\
\text { - Grating scale } \\
\text {-Optical encoder }\end{array}$ & 10 \\
\hline $\begin{array}{l}\text { 5. Light source and } \\
\text { illumination }\end{array}$ & $\begin{array}{l}\text { - Common light source } \\
\text { - Target light source type } \\
\text { - Point source } \\
\text { - Linear source } \\
\text { - Planar source }\end{array}$ & 4 \\
\hline $\begin{array}{l}\text { 6. Selection and adjustment } \\
\text { of optical elements }\end{array}$ & $\begin{array}{l}\text { - Geometric optics elements } \\
\text { - Physical optics elements } \\
\text { - Newly developed optical elements } \\
\text { - Error distribution, mounting and calibration of optical elements }\end{array}$ & 4 \\
\hline $\begin{array}{l}\text { 7. Optoelectronical detection } \\
\text { and devices }\end{array}$ & $\begin{array}{l}\text { - Performance of detectors } \\
\text { - Principle and classification of detectors } \\
\text { - Application instances }\end{array}$ & 4 \\
\hline $\begin{array}{l}\text { 8. Mechanical movement } \\
\text { and positioning }\end{array}$ & $\begin{array}{l}\text { - Basic criteria in structure design } \\
\text { - Micro-displacement devices } \\
\text { - Optical and optoelectronical alignment } \\
\text { - Axial alignment }\end{array}$ & 4 \\
\hline $\begin{array}{l}\text { 9. Principle of typical } \\
\text { instruments }\end{array}$ & $\begin{array}{l}\text { - Laser interferometer } \\
\text { - Optical profiler } \\
\text { - Confocal microscope } \\
\text { - Projector }\end{array}$ & 10 \\
\hline
\end{tabular}

\subsection{Feature and problem of OIC}

Determined by the interdisciplinary feature of optical instruments, OIC is also a comprehensive professional course. It can be seen from the contents that this course should take Physics, Applied Optics, Physical Optics, Experiment on Photoelectronic Imaging Principle and Technology, Error Theory and Data Procession, Foundation of Precision Mechanism Design, Fundamentals of Control Theory as the prerequisites. Since the students may have different interests and professional foundation, their obstacles may occur at different chapters and points. It is impossible for the teacher to explain every point during limited in-class time, so after-class one-to-one communication is necessary. The low lecturer/ student ratio prevents personalized question time.

Moreover, OIC is focused on various engineering applications rather than profound theories. Lacking of systematic study will confuse the students. Good summaries of the main content and the requirements of final examination should be given timely and to every student. 


\section{INTERACTIVE TEACHING AND LEARNING WITH SMART PHONE APP}

Rain Classroom is a free smartphone App for interactive teaching and learning. It is jointly developed by xuetangx.com and Tsinghua University Online Education Office. The purpose is to enhance the classroom teaching experience, so that teachers and students interact more. Rain Classroom adopts a complex information technology into the PC software PowerPoint and smartphone App WeChat. Using the App, the teacher can push a MOOC video, voice exercises, preview and review materials to the mobile phone software, and receive students' timely feedback. Also the bullet screen during class provides an interesting teaching interactive solution for the teachers and students in traditional classroom. In the procedure of teaching, Rain Classroom has covered each teaching link before class, after class, for the teachers and students to provide a complete three-dimensional data support.

\subsection{Bullet screen during class}

Due to the relatively introverted personality and long-time habit, most of the students are inactive in in-class communications. We tried to turn on the bullet screen function after explanation of important topics. The students could post their comments on the screen through Rain Classroom App. It was anonymous so most of them were willing to communicate. The difficulty turned from making them talk to guiding them talking right. We saw complaints about the course, questions about the final examination, confessions and other curious information. In this semester, we only tried this for several times and have not fixed a proper way of guiding them. However, we did learn more about their thoughts and difficulties, which helped us prepare better for the next class.

\subsection{Preview and review material offline pushing}

Traditional way of handing out courseware is sending emails or direct copy by USB disk. It is fast but received no response. We pushed the preview material before class and review materials after class with Rain Classroom. We could check the name of the student who had reviewed the materials. The best point was that the students could leave message or questions directly under the materials. And an even better point was we could leave our replies after their comments. It was just like leaving messages in the social software, which means freedom and casual for both of us.

\subsection{In-class quiz}

For emphasis on the important topics and help the student to be familiar with the question types in final examination, we posted in-class quiz. We only need to make simple PowerPoint pages and Rain Classroom could turn them into a quiz on the smartphone. The students could see their scores after handed in the answers. We could see the answers of each of them and the statistics of each question. This could help both of us understand the topic and the level they had learnt.

\section{FEEDBACK AND DISCUSSION}

After the first trial for a semester, we did an investigation to check the feedback of the students towards the new communication method. The related questions are listed in Table 2.

Table 2. Questionnaire for the smart-phone-app-based teaching and learning.

\begin{tabular}{|c|l|l|}
\hline No. & \multicolumn{1}{|c|}{ Question } & \multicolumn{1}{c|}{ Options } \\
\hline 1 & $\begin{array}{l}\text { What is your opinion on } \\
\text { the introduction of Rain } \\
\text { Classroom App? }\end{array}$ & $\begin{array}{l}\text { A. It is very helpful. It should be used earlier! } \\
\text { B. It is helpless and formalism. } \\
\text { C. I do not like it because it will draw my attention from study! } \\
\text { D. Other, please specify }\end{array}$ \\
\hline 2 & $\begin{array}{l}\text { If you hold positive } \\
\text { opinion on Rain } \\
\text { Classroom App, what is } \\
\text { the reason? }\end{array}$ & $\begin{array}{l}\text { B. The ofllet screen during class increases the interaction, and makes the } \\
\text { boring } \\
\text { the content, and is helpful. } \\
\text { C. In-class quiz helps me to prepare for the final exam. } \\
\text { D. Other, please specify }\end{array}$ \\
\hline
\end{tabular}

We distributed 150 questionnaires and received 124 effective feedbacks. The results are plotted in Fig. 1. 


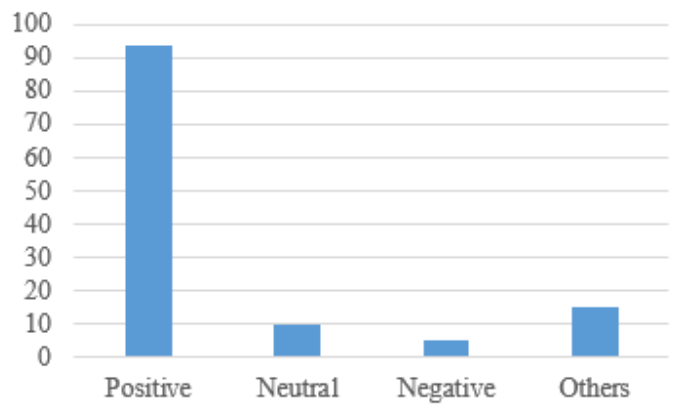

(a)

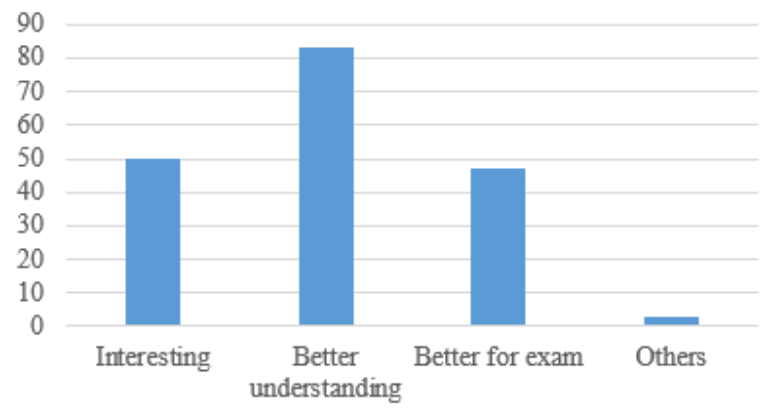

(b)

Figure 1. Feedback of the students about their attitudes towards the interactive teaching based on smart phone Apps. (a) is their attitudes and (b) is the reason for holding positive attitudes.

From Fig. 1(a) we can see that $76 \%$ of the students held positive attitudes to the novel teaching mode. Some of the students even expressed that if the software were introduced earlier, he could learn other courses much better! That is the best feedback for us. From Fig. 1(b) we know that the trial do help them in understanding the course better. Also they were attracted by the bullet screen and benefit from the in-class quiz. Neutral and Negative attitudes are below $12 \%$. The rest of them raised questions or suggestions in the "Others" option. Some typical ones can be classified into three types and are listed as follows.

(1) Useful but limited

- It is useful only because we can get the courseware conveniently and timely.

- It is helpful but not much.

- It is helpful but not suitable for every course or everyone.

- It is helpful in sharing the courseware but no substantial improvement to the learning.

(2) Useful but also harmful

- The App is good, but many classmates take advantage of this opportunity to play with the smart phone!

(3) Not good as traditional mode

- It is not convenient. I like the courseware files in computer.

- I do not need it because I can master all the knowledge during class explanation.

The first type was ambiguous and we figured out that the possible problems may lie in that we failed to attract their attention on why we should learn this course or how to learn it well. In their eyes, the new teaching mode was just a game and had no relationship with the course itself. The second type was a common social problem because even for a mature adult, it is difficult to be self-controlled enough. We thought it was an exact right chance for them to learn to get along peaceful with the smartphone. The third one had some relationship with the first one. Because the students could not see substantial improvement of the learning procedure, they did not accept the new teaching mode. Nevertheless, we believe teaching and learning with smartphone is the development trend and we will try to solve the above problems in our next trial.

\section{CONCLUSION}

In this paper, we introduced our first trial of introducing smartphone and social software into the course of Optoelectronic Instruments, a comprehensive professional course for senior students. We received instant feedback from students through bullet screen, push preview and review materials and post in-class quiz. Investigation showed that $76 \%$ of the students enjoyed the new interactive tool, acknowledging its help in understanding the topic better, improving inclass interaction, and after class communications. Still we have many problems to be solved and we will figure out new approaches for next trial. We believe that teaching and learning with information tools is the development trend and will make more contribute to this area. 


\section{ACKNOWLEDGEMENTS}

The authors appreciate the free software Rain Classroom.

\section{REFERENCES}

[1] Shavinina L V, Loarer E. "Psychological evaluation of educational multimedia applications," European Psychologist 4(1), 33 (1999).

[2] Livingstone S, Bober M. "Taking up online opportunities? Children's uses of the Internet for education, communication and participation," E-Learning and Digital Media 1(3), 395-419 (2004).

[3] Georgiev T, Georgieva E, Smrikarov A. "M-learning-a New Stage of E-Learning," International conference on computer systems and technologies-CompSysTech. 4(28), 1-4 (2004).

[4] Cochrane T. "Learning with wireless mobile devices and social software," Proceedings of the 23rd annual ascilite conference: Who's learning? Whose technology? 2006, 143-146 (2006).

[5] Yu F, Conway A. R. "Mobile/smartphone use in higher education," Proceedings of the 2012 Southwest Decision Sciences Institute, 2012, 831-839 (2012).

[6] Gikas J, Grant M M. "Mobile computing devices in higher education: Student perspectives on learning with cellphones, smartphones \& social media," The Internet and Higher Education 19, 18-26 (2013). 